\title{
Nonlinear Stochastic Convergence Analysis of Regional Unemployment Rates in Poland
}

\author{
JOANNA TYROWICZ ${ }^{* \dagger}$ \\ University of Warsaw \\ National Bank of Poland \\ Rimini Centre for Economic Analysis \\ PIOTR WÓJCIK \\ University of Warsaw
}

\begin{abstract}
This paper analyzes convergence of unemployment rates in Poland at the local level by testing nonlinear convergence, applying the modified KSS-CHLL test for each pair of territorial units. The results suggest that actually the convergence is a rare phenomenon and occurs only in 3227 cases out of potential over 70000 combinations. This paper inquires which systematic reasons contribute to this phenomenon.

There are some circumstances under which unemployment convergence should be more awaited than in the others. These include sharing a higher level territorial authority, experiencing similar labour market hardship or sharing the same structural characteristics. For each of these three criteria we analyse the frequency of the differential non-stationarity within groups as evidence of convergence or "catching up".
\end{abstract}

Keywords: nonlinear stochastic convergence, regional unemployment, Poland

JEL Classifications: C1, C2, C3

\section{Introduction}

Eastern European transition economies frequently witnessed dramatically high unemployment rates throughout the 1990s. Currently, national average rates seem to have dropped to moderate levels, providing some evidence in support of the hypotheses of the increasing EU-wide cohesion. However, natural restructuring processes affected local labour markets asymmetrically, leaving some regions with still rates approaching 30 per cent or even 40 per cent thresholds.

\footnotetext{
${ }^{*}$ Authors are grateful to the participants of GLUNLAB2 and AIEL conferences as well as anonymous referees for valuable comments. The remaining errors are ours. Part of research was done when Joanna Tyrowicz was a visiting Columbia University within the Fulbright Scholar programme, whose support is gratefully acknowledged.

†Corresponding author: jtyrowicz@wne.uw.edu.pl

(c) 2010 Joanna Tyrowicz, Piotr Wójcik. Licenced under the Creative Commons AttributionNoncommercial 3.0 Licence (http://creativecommons.org/licenses/by-nc/3.0/). Available at http://rofea.org.
} 
As demonstrated by Tyrowicz and Wójcik (2010b) regional unemployment rates distributions demonstrate not only unprecedented stability as measured by $\sigma$ convergence, but also strong $\beta$ divergence.

While it is typical for some regions of Europe, Overman and Puga (2002), the lack of convergence among regions with so high unemployment levels seems especially worrisome. The phenomena of local unemployment rate divergence are sometimes explained by diversified structure with respect to industry composition and economic outlooks at the eve of transition, Góra and Lehman (1995). Such an approach, on the other hand, neglects the potential impact of cohesion policies as well as spatial factors.

In this paper we inquire whether some - so to say - purposeful stochastic convergence patterns emerge among Polish regions at NUTS4 level in as far as registered unemployment rate is concerned. We provide an analysis of stochastic convergence for each pair of the 379 local labour markets (NUTS4 level units) from three perspectives. First, we analyse whether within some NUTS2 regions stochastic convergence is more common than within some others. This research question is motivated by the fact that although active labour market policies (ALMPs) are implemented at NUTS4 level, de iure they are coordinated by the regional authorities (NUTS2 level units). Secondly, we test whether stochastic convergence occurs more frequently among pairs from the same or adjacent decile groups of the initial unemployment rates distribution. Finally, we use clustering techniques to provide reliable grouping of local labour markets units based in the characteristics of the unemployed. These characteristics comprised the shares of long-term unemployed, youth, living in the rural areas and unemployed with none or negligible experience, outflows rate as well as inflows. Indeed, local labour markets differ in these characteristics, forming clusters of units strongly homogenous within and heterogeneous between.

We find little evidence supporting the hypothesis that coordination by regional level authorities contributes to more convergence among local labour markets located in the same region. In fact, belonging to the same region correlates relatively weakest with the convergence. It seems that these are the structural characteristics that "predict" best the occurrence of stochastic convergence, while the initial unemployment level performs comparably in terms of convergence, but much weaker in terms of catching up. It seems that the coordination by the regional level authorities does not contribute to more social cohesion, while alike characteristics seem to exemplify similar difficulties in overcoming the labour market problems. The paper is organised as follows. In section 2 we briefly discuss the literature in the field, demonstrating how this study contributes to the understanding of local unemployment levels dynamics. We further move to describing methodology in section 3 and data in section 4. Results are discussed in section 5. The concluding remarks provide some policy implications of the findings and suggest some directions for future research. 
TYROWICZ, WÓJCIK Nonlinear Stochastic Convergence of Unemployment

\section{Literature Review}

¿From a time-series perspective one can analyze the so-called stochastic convergence. Applied to GDP per capita it examines whether permanent movements in income of one country (or region) are associated with also permanent movements in income of another countries (regions). Therefore, stochastic convergence implies that differences in incomes between countries or regions cannot contain unit roots. Consequently, the differences need to be stationary.

Early empirical studies on testing stochastic convergence for GDP per capita include Campbell and Mankiw (1989) and Cogley (1990). However, the concept was in-depth elaborated only few years later by Carlino and Mills (1993), who focus on US states GDP performance. Subsequent works comprise Bernard and Durlauf (1995), Greasley and Oxley (1997), St. Aubyn (1999) and Cellini and Scorcu (2000). On the other hand, this method has been argued to potentially classify as non-converging regions which consistently experience more of the asymmetric external shocks. Armstrong and Taylor (2000) suggest that if the speed of adjustment is slow while external shocks strong, divergence may emerge as a statistical artefact in spite of effective convergence exhibited by the processes. Therefore, cointegration tests should encompass possible structural breaks, which may make the interpretation of the findings relatively troublesome.

The method of stochastic convergence has also been applied to analysing unemployment. This last approach is applied by Bayer and Juessen (2006) for Germany and Gomes and da Silva (2006) for the case of Brazil. Bayer and Juessen (2006) perform a unit-root test on regional unemployment rate differentials using Mikrozensus data for West Germany over the 1960-2002 time span. They find moderate evidence in support of the convergence hypothesis, namely when controlling for structural breaks unit-root is rejected for the majority of regions. Similarly, Gomes and da Silva (2006) for the six metropolitan regions of Brazil find strong evidence of hysteresis and unemployment regional differential persistence, especially strong for the case of Rio de Janeiro.

In the context of transition, basing on the findings of Tyrowicz and Wójcik (2010b), one can state that for the majority of NUTS4 regions in Czech Republic, Poland and Slovakia little evidence in support of the convergence hypothesis may be found. In the case of Czech Republic the null was consistently rejected, while in the case of Slovakia and Poland data suggest strong persistence of regional unemployment rate differentials despite inclusion of trend and allowing for structural breaks. Summarising, these findings suggest that the NUTS4 regions follow different patterns of evolution with respect to the national average. The question is if these patterns resemble each other.

Incorporating the spatial context is more and more present in the literature in both macrolevel and micro-level studies. On a micro-level Wasmer and Zenou (2006) construct a theoretical search model in which, when transportation costs are introduced, a zone exists where both the employed and the unemployed co-exist and are not mobile, while the size of this zone depends positively on the magnitude of the transportation costs. On the empirical side 
Rogers (1997) develops a precise measure of commuting costs in municipal employment growth dynamics. Martin (2004) includes a spatial mismatch index in estimating the effectiveness of unemployment-to-employment flows for Black communities in American cities, finding that metropolitan employment shifts increased the Black unemployment rates by considerable amounts and these negative effects were not fully compensated by labour mobility.

For the former level of analysis, Great Britain, Germany, Italy and the Netherlands seem to be the most analysed cases (cfr. Manning (1994), Molho (1995) and Buettner (1999) among others). Some attention has also been devoted to the EU-wide regional analyses. Overman and Puga (2002) suggest that unemployment rates are much more homogenous across neighbouring areas than across regions in the same EU country, while common characteristics of adjacent regions - like sectoral structure or unemployment composition - do not account for the whole of this spatial effect. Niebuhr (2003) and, subsequently, Niebuhr and Stiller (2004) and Bräuninger and Niebuhr (2005) elaborate further this issue explicitly accounting for spatial weights matrices. Findings suggest clustering of the high/low unemployment regions with some cross-border clustering.

There has been considerably less research on transition economies. Ferragina and Pastore (2008) suggest that unemployment levels in CEECs exhibit patterns rare among the so-called mature economies. Varied theoretical and empirical approaches attempting to link transition and economic integration suggest that labour market phenomena seem to be an indispensable element to understand the dynamics of these processes. Südekum (2003) uses an augmented wage curve incorporating increasing returns to scale and agglomeration factors in order to address the observed phenomena of polarisation between a low unemployment developed core and a high unemployment depressed periphery. At the same time, Overman and Puga (2002) argue that international trade and inflow of capital from abroad tend to - if anything - reinforce and not to weaken the existing patterns of unemployment.

There seems to be a consensus in the literature that via labour mobility and trade flows contribute to the spillover effects of the local employment growth/decreases to other regions. The spread of this effect depends on the labour mobility (relocation costs), with relatively low distance decay consistent with everyday commuting. In Molho (1995), spillovers are strongest after a lag, which he interprets as corroboration of migration underpinnings of the findings, while localised spatial interactions are interpreted to support the hypotheses of commuting adjustments in response to shocks. Furthermore, the spillover - by the phenomena of migration, commuting and interregional trade - may well have a reversal nature in the form of a "returning wave" .

What seems to be missing in the literature so far is the understanding, that authorities of the macro-regions analysed may have insufficient tools to intervene in the most deprived regions. For example, consider a case of a local labour market characterised by excess of labour

\footnotetext{
${ }^{1}$ Unfortunately, reliable data on labour mobility are unavailable for Poland.
} 


\section{TYROWICZ, WÓJCIK Nonlinear Stochastic Convergence of Unemployment}

supply. Among the equidistant other local labour markets, some are characterised by similar conditions, while other experience labour shortages (at least in some segments of the market). Consider now, that except for the local labour market administrative borders, there exist also supra-administrative borders in some form - for some of the local labour markets for example information about the vacancies may be available at lower cost than for the others. In such a setting, persisting regional unemployment rate differentials may be a consequence not that much of the relocation costs, but effectively result from differentiated costs of informational access. This is exactly the area of further analyses.

More explicitly, all of the above mentioned approaches seek stochastic convergence with reference to a national average benchmark. Namely, they try to test whether relative local unemployment rate converges to a national average - in principle an "artificial" number computed based on a number of the realisations of potentially independent processes. In this paper we take a different approach. Namely, instead of using an "artificial" national average unemployment rate as a benchmark, we test the cointegration hypothesis for every pair of NUTS4 units (poviats). In doing so, we have adopted three main grouping criteria: belonging to the same NUTS2 region, belonging to the same or adjacent decimal groups of the initial unemployment rate distribution ${ }^{2}$ and belonging to the same cluster based on structural characteristics of the local labour markets. The details of the analytical strategy are discussed in the next section.

\section{Method}

Formally stochastic convergence for a number of countries or regions means that the long-term forecasts of a variable of interest for all countries or regions $(i=1, \ldots, n)$ equalise at some fixed time $t$, (Bernard and Durlauf 1995):

$$
E\left(y_{1, t+k}-y_{i, t+k} \mid I_{t}\right)=0, \quad \forall i>1, \text { for } \quad k \longrightarrow \infty
$$

where $y_{i, t+k}$ is the logarithm of variable of interest for region $i$ at time $t+k$, and $I_{t}$ is all the information available at time $t$. Using the concepts of unit roots and cointegration, the convergence test implies examination whether the difference $y_{1, t+k}-y_{i, t+k}$ in equation (1) is a zero mean stationary process, thus implying cointegration between all geographical units considered. Convergence in unemployment rates for two countries or regions, $i$ and $j$, implies that their unemployment rates must have a cointegrating vector $[1,-1]$. However, this concept of convergence has been criticised as rather strict, since for this kind of strong convergence to exist it is necessary that the long-run forecast of difference between the two regions is equal to zero.

\footnotetext{
${ }^{2}$ Tyrowicz and Wójcik (2010a) find using kernel density estimates that mobility between the middle groups is more frequent than within the high and the low end ones.
} 
There is an alternative time-series definition of convergence, also known as catching-up. This definition means that the differences decrease over time, (Bernard and Durlauf 1996), and can be written as:

$$
E\left(y_{1, T}-y_{j, T} \mid I_{t}\right)<\left(y_{1,0}-y_{j, 0}\right)
$$

where 0 refers to the present and $T$ to some time in the future. The difference between the two time series should also be stationary, but now the time trend can be deterministic. Again, the only cointegrating vector between the two local labour markets can be [1, -1]. Intuitively, convergence will appear if in the long run values of two time series equalize, while catching-up would mean reducing the distance in the long run.

Following Bernard and Durlauf (1995), stochastic convergence occurs if relative logarithm of a variable under scrutiny, $y_{i j t}$, follows a stationary process, where $y_{i j t}=\log Y_{i t}-\log Y_{j t}$, and $Y_{i t}$ is the real value for unit $i$, and $Y_{j t}$ is the real value for unit $j$. Both series have to be integrated of the same order (non-stationarity in most cases means being integrated of order one). If the difference is stationary, it means convergence (or catching-up) between countries (or regions) $i$ and $j$. The non-stationarity can be tested using the conventional augmented Dickey-Fuller $(\mathrm{ADF})$ regression in the following form:

$$
\Delta y_{i j t}=\alpha_{i}+\gamma_{i} t+\beta_{i} y_{i j t-1}+\sum_{k=1}^{p} \theta_{i j k} \Delta y_{i j t-k}+\epsilon_{i j t}, \quad t=1, \ldots, T
$$

where $i=1, \ldots N, j=i+1, \ldots, N$ constitute all possible pairs of regions, and $k=1, \ldots, p$ ADF lags.

The distinction between long-run convergence and convergence as catching-up, (Oxley and Greasley 1995), can be derived from estimating the equation (3). First, if $y_{i j t}$ contains a unit root (i.e. $\beta_{i}=0$ ), levels of unemployment for regions $i$ and $j$ diverge over time. Second, when $y_{i j t}$ is stationary (i.e. $\beta_{i}<0$, which means no stochastic trend) and (a) the absence of the deterministic trend (i.e. $\gamma_{i}=0$ ) indicates long-run convergence between regions $i$ and $j$; (b) existence of the deterministic trend (i.e. $\gamma_{i} \neq 0$ ) indicates catching-up (or narrowing of the differentials) between regions $i$ and $j$.

However, equation (3) may not be able to detect convergence if $y_{i j t}$ contains nonlinearity. Kapetanios, Shin and Snell (2003) provide an extension of the augmented Dickey-Fuller unit root test in order to include potential nonlinearity in a form characterised by the Smooth Transition Autoregressive (STAR) process:

$$
\Delta x_{i j t}=\sum_{k=1}^{p} \rho_{k} \Delta x_{i j t-k}+\delta x_{i j t-1}^{3}+v_{i j t}
$$

where 
TYROWICZ, WÓJCIK Nonlinear Stochastic Convergence of Unemployment

$$
x_{i j t}=y_{i j t}-\hat{\alpha}-\hat{\beta} t
$$

is the de-meaned and de-trended series with $\hat{\alpha}$ and $\hat{\beta}$ resulting from the ordinary least squares estimation of $y_{i j t}$ on an intercept and linear trend. Within this framework one can test the null hypothesis of nonstationarity $\left(H_{0}: \delta=0\right)$ against the alternative of stationarity $\left(H_{A}: \delta<0\right)$.

Although incorporating nonlinear convergence, these test cannot verify the significance of the deterministic trend, thus distinguish between long-run converging and catching up (in case of nonlinear stationarity). Therefore, Chong, Hinich, Liew and Lim (2008) modify the Kapetanios et al. (2003) unit root test and Oxley and Greasley (1995) time series test of convergence to allow for this differentiation. They include an additive intercept term $(\mu)$ and the trend component $G($ trend $)$ into equation (4) which gives:

$$
\Delta y_{i j t}=\mu+\sum_{k=1}^{p} \rho_{k} \Delta y_{i j t-k}+\delta x_{i j t-1}^{3}+\phi G(\text { trend })+\epsilon_{i j t}
$$

where $y_{i j t}$ is the original series of interest and not the de-meaned and de-trended series $x_{i j t}$. $G\left(\right.$ trend) is the linear $(t)$ or quadratic $\left(t^{2}\right)$ trend component - the latter referred in their paper as linear nonlinear trend.

The statistical interpretation of equation (6) is similar to that of Oxley and Greasley (1995). If the modeled differential contains a nonlinear unit root $(\delta=0)$, the unemployment level of the two administrative units is diverging over time. The absence of nonlinear unit root $(\delta<0)$ indicates either catching up process, when the deterministic trend is present $(\phi \neq 0)$, or nonlinear long-run convergence if there is no deterministic trend $(\phi=0)$. The statistical significance of parameters $\delta$ and $\phi$ can be tested by calculating $t$ statistics, but their asymptotic distribution within this framework is unknown. Chong et al. (2008) simulated the corresponding critical values from 5000 replications for various sample sizes. The resulting critical values are tabulated in the paper.

We apply the modified KSS-CHLL nonlinear unit root test. We use this methodology to examine the existence of stochastic convergence of relative unemployment rates (in relation to country average) between poviats of Poland - the cross-sectional dimension of the unemployment convergence. However, as already discussed in Tyrowicz and Wójcik (2010b), convergence to the national average - as tested with the use of panel stochastic convergence tests can rarely be confirmed. This paper contributes by verifying the pairs of local labour markets among each other. Technically, we test for stationarity of the difference between unemployment rates for all possible pairs of poviats: $u_{i j t}=\log U_{i t}-\log U_{j t}$, where $U_{i t}$ is the relative unemployment rate in poviat $i$ at time $t$ and $U_{j t}$ is the relative unemployment rate in poviat $j$ in the same period.

In fact, the adequacy of testing the stationarity in the context of nonlinearity is particularly important in our analysis. Namely, while the first half of the analysed period is characterised by 
stark increases in the unemployment rate, as of the maximum in 2004 the trend was systematically reversed. Both increasing and decreasing trends were frequently non-linear and the size of an increases and subsequent decreases in unemployment rate were significantly differentiated among poviats. The stationarity test that would not encompass nonlinearity, runs the risk of rejecting the null hypothesis (of nonstationarity) in too few cases. Therefore, we decided to use the non-linear test for convergence, as the log differential for many pairs shown non-linear patterns.

When linear ADF-GLS and nonlinear KSS-CHLL tests were compared for Poland, the results proved to be very similar casewise, but less frequent for the ADF-GLS tests. As a matter of fact, we also performed the classical ADF test, but it found stationarity (convergence or catching-up) only for 1943 pairs (2.7\%). Similarly to Pesaran, Smith, Takashi and Hvozdyk (2009), we also used the extension of the ADF test with more power, namely ADF-GLS, Elliott, Rothenberg and Stock (1996), but the results were very similar. Convergence was found for 2079 pairs of poviats in a linear tests and 3227 for the nonlinear tests. In addition, the ADFGLS test does not allow for differentiation between convergence and catching-up phenomena.

The alternative to use nonlinear unit root tests would be to apply a recent development by Pesaran (2009). The tested properties advertised in favour of an extension of ADF tests that raises via introducing a GLS approach, following Elliott et al. (1996). Monte Carlo simulations on pairwise cointegration in $\mathrm{GDP}^{3}$ prove that indeed ADF-GLS is superior to other specifications. However, KSS-CHLL was not included in the tests competition by Pesaran (2009), while data frequency and the nature of the analysed processes was probably less susceptible to the nonlinearities. Pesaran et al. (2009) included the nonlinear tests as well and found that rejection frequencies with a non-linear alternative were substantially higher in most cases.

\section{Data}

We use a unique data set combining the official registry unemployment data from the Central Statistical Office with Ministry of Labour and Social Affairs database on the structure of unemployment at a local level. Data set covers the period of January 1999 till December 2009 of monthly data for 379 local labour markets at policy relevant NUTS4 level. It includes registry information about the number of job seekers, reported vacancies, basic structural characteristics of the local labour markets (i.e. share of inhabitants in the rural areas, etc.) and local labour market dynamics (i.e. vacancies and outflows into employment as well as inflows into unemployment ${ }^{4}$ ). The choice of time boundaries was dictated by the data availability and seems to

\footnotetext{
${ }^{3}$ Subsequently, also testing PPP in a pairwise form, Pesaran et al. (2009).

${ }^{4}$ Since these are registry data, they suffer from many well-known shortcomings. First of all, vacancies are systematically underreported and therefore cannot serve for more than a proxy of the employers needs, Meyer and Sullivan (2003). Consequently, we rely on outflows rates rather than vacancies rates in providing the basis for clustering.
} 


\section{TYROWICZ, WÓJCIK Nonlinear Stochastic Convergence of Unemployment}

bear no serious limitations for the possible results except one. Namely, labour market evolutions have commenced in Poland in early 1990s. Unfortunately, NUTS4 data prior to 1999 do not exist, while only in 2001 separate metropolitan municipalities were established. Therefore, the study covers the periods when the differentials already existed and were subject by some cohesion policies. Nonetheless, the data set covers periods of both increases and decreases in the national unemployment rates.

Based on these data, we were able to define our three criteria of analysis. First of all, each of the NUTS4 unit belongs to a policy relevant NUTS2 unit. In Poland 379 poviats are located in 16 voivodships. Many of the social and labour market policies are implemented at community or poviat level but coordinated by NUTS2 authorities. Although there is no hierarchical dependence, NUTS2 authorities frequently distribute the financing to the implementing units. Lower level community authorities are always free to increase the financing, but it is a rare phenomenon.

Secondly, using the monthly reports by local labour offices to the Ministry of Labour and Social Affairs, we were able to generate structural variables describing the composition of the unemployed pool as well as local labour market dynamics. Namely, we have computed the shares, ratios and trends over the 2000-2006 of the following variables: inflows rate, outflows rate, share of long-term unemployed, share of youth, share of rural areas inhabitants and share of unemployed with low or no qualifications (as well as over- or underrepresentation of women in each of these groups). We subsequently used these variables to perform clustering of the poviats. We chose to use hierarchical clustering with Ward linkage. This procedure has indicated 10 groupings as the optimal solution acording to pseudo $T^{2}$ stoping criterion (which is the modification Duda-Hart stopping rule) and Sarle's Cubic Clustering Criterion (CCC). CalinskiHarabasz pseudo-F index also took relatively high values for this solution. Figure 1 presents geographical distribution of particular clusters.

Indeed, groupings of poviats differ. The third cluster is clearly a municipal one, while the third and fourth cluster are characterised by very high rates of rural areas inhabitants, but also lowest rates of long-term unemployed. The sixth and the tenth cluster have least unemployment resulting from the restructuring, while the sixth is also an agglomeration cluster (no unemployed living in the rural areas). Fourth and seventh cluster are opposite in a sense that they score highest in long term unemployment and also very high in the rural unemployment. Clearly, these characteristics correspond to different labour market outlooks.

Finally, based on the distribution of unemployment in the first period (December 1998) we have generated ten equal sized groups (decile groups). These decile groups do not correspond to the above discussed voivodship structure. Namely, each NUTS2 unit contains both high and low unemployment level NUTS4 units. Figure 2 presents the geographical distribution of poviats across the decile groups.

Clearly, highest unemployment rate is observed in the north of Poland (mainly warminsko- 
Review of Economic Analysis 3 (2010) 59-79

Figure 1: Clusters of Poviats

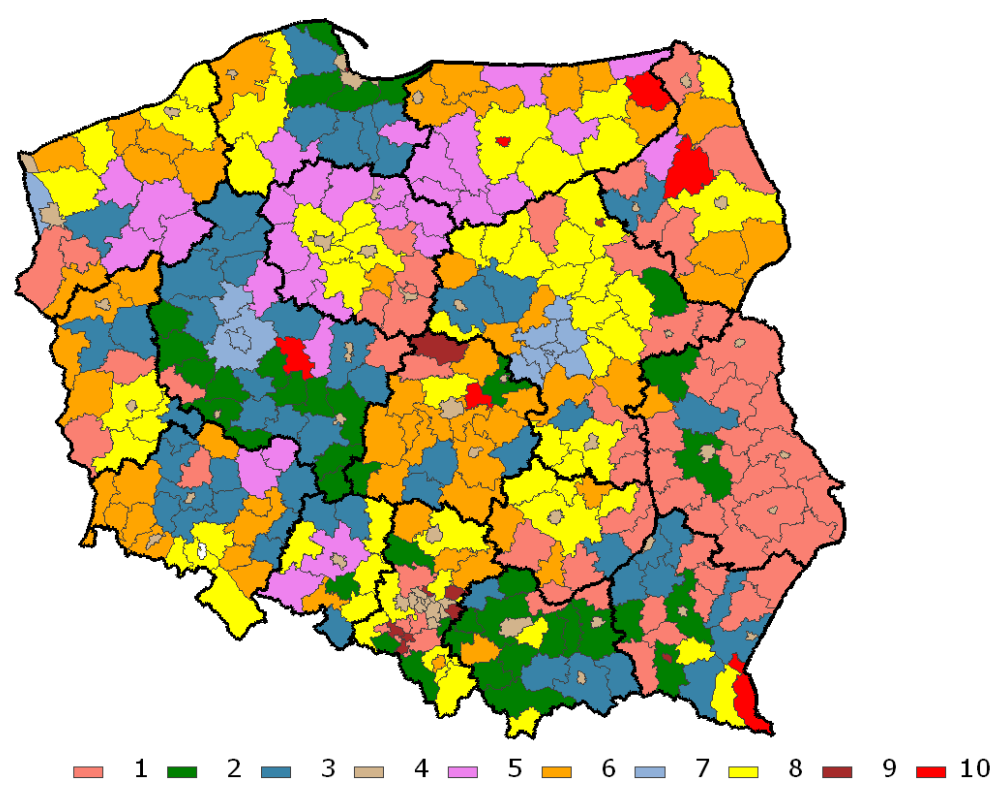

Figure 2: Decimal Groups of Poviats in December 1998.

Darker shades signify higher unemployment rate.

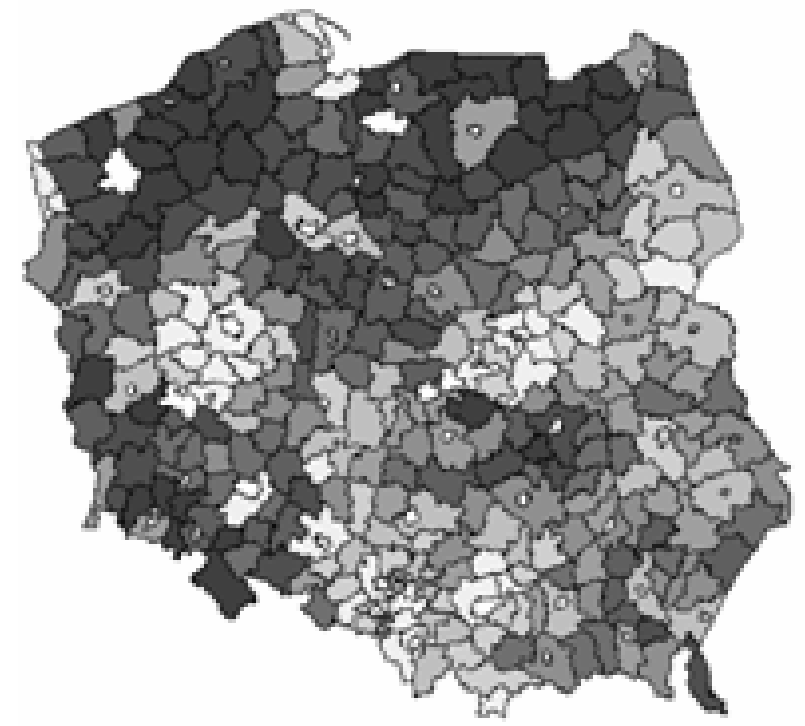

mazurskie and zachodniopomorskie region). On the other hand, with the exception of Eastern Poland, each region has highest and lowest unemployment local labour markets. There is also 
TYROWICZ, WÓJCIK Nonlinear Stochastic Convergence of Unemployment

a visible tendency that high and low unemployment regions - so to say - "cluster" in space.

\section{Results}

A necessary condition for testing cointegration between two series is that both are non-stationary and integrated of the same order. In fact, a stationary and a non-stationary time series may be cointegrated with a trivial, unit cointegrating vector. Since such cases are uninteresting, we first test for the order of integration of data series on $(\log )$ unemployment rates for all single poviats and the country level. Out of 380 (including the average for Poland) monthly time series none appeared to be stationary. Vast majority seemed to diverge from the average with respect to unemployment rate level. For sixteen poviats indication of long-run convergence was found, while another two seemed to face the catching-up process. The converging or catching-up poviats names are listed in Table 5 in the Appendix 5 .

After testing for convergence between the average and regional unemployment rates we applied similar procedure to all possible pairs of poviats, to see whether we can observe similarly behaving groups of regions. The 379 poviats were combined into all possible 71631 pairs and cointegration between them was tested in the form described in equation (6). All statistical tests were performed on $1 \%$ significance level. We found 3949 significant long-run relationships of regional relative unemployment rates (for $I(1)$ series), among which 3227 were interpreted as indication convergence and 722 of the catching-up phenomenon. The rest of pairs of poviats faced divergence in terms of relative unemployment rates.

We subsequently checked whether convergence patterns have spatial, structural or unemployment level dimensions. Firstly, we analysed if the poviats that have long-run relationship with respect to relative unemployment rate are close to each other institutionally and also geographicaly (belong to the same NUTS2 region - voivodship). Secondly, we inquired whether initially (Dec 1998) they were in the same decile group with respect to unemployment level. Finally, we also verified if structurally similar NUTS4 units are more likely to exhibit stochastic convergence.

The upper panel of Table 1 contains the summary of the spatial dimension of cointegration (the percentage of pairs of poviats from different voivodships facing convergence of relative unemployment rates). The rows and the columns contain information for subsequent voivodships. Relatively larger numbers on the diagonal indicate convergence of unemployment within

\footnotetext{
${ }^{5}$ Among the poviats with indication of long-run convergence process most had relatively high or moderate initial unemployment rate. Only three of them (namely skierniewicki, kaliski and Dabrowa Gornicza city) faced relatively low unemployment rates. As far as catching-up process is concerned, the two poviats had rather moderate initial rates of unemployment. The summary of number of poviats for which unemployment rate exhibits relationship to the national average can be found in Table 4 in the Appendix, both with respect to voivodship of origin and with respect to initial decimal group. Converging and catchingup poviats come rather from different voivodships. Regions facing long-run convergence are located on the opposite ends of unemployment rate values (high or low decile groups), while these catching-up had rather high (but not the highest) initial unemployment rates.
} 
voivodships - none of which could be observed. The strongest within-voivodship convergence is observed in mazowieckie, slaskie and wielkopolskie - three richest of the Polish regions. More than $10 \%$ of cointergating relationships for poviats from these voivodeships if found with poviats from the same voivodeship. On the other hand, lowest values at the diagonal may be observed in lubuskie, malopolskie and podkarpackie - i.e. poorer regions and also for relatively richer pomorskie. The poviats from different voivodships are often converging with poviats from richest region - mazowieckie (10-20\% pairs).

Surprisingly many cointegrating patterns are found with poviats of zachodniopomoskie region (Northwest Poland), which traditionally scores second or highest unemployment rate. Also catching up is most frequent in the case of poviats from this voivodship - both within and between. This may however signify considerable changes in the local labour supply in this region. Namely, because of the proximity with Germany and migration embedded in the local tradition, zachodniopomorskie is recognised as an important sending region, Kaczmarczyk and Tyrowicz $(2008)^{6}$. Changing labour supply affects both the nominator and the denominator of the unemployment rate, thus yielding more volatility than in other regions of Poland.

Analysing adjacent regions, there seem to be evidence of convergence between poviats located on the East of Poland - between lubelskie, podkarpackie, part of mazowieckie and podlaskie. These regions have relatively more converging and catching up pairs among between each other. On the other hand, another eastern region - warminsko-mazurskie - does not confirm this pattern. While this region is consistently characterised by the highest unemployment rate in Poland, it demonstrates highest number of cointegrating relations with the smallest Polish region - opolskie. Thus, one can conclude that to some extent convergence pattern of regional unemployment rates has spatial dimension, but it is far from conclusive.

The catching-up process seems also relatively less frequent and more diversified than convergence. Average diagonal reports a mean of the diagonal values and it is nearly $30 \%$ lower for catching up. This implies that within-region patterns are weaker for catching up than for convergence, which further corroborates the doubts in the efficiency of regional level coordination of labour market policies.

Another way of summarizing the results consists of considering the potential distributional effects. The poviats were divided into 10 equal sized groups with respect to the unemployment rate level in December 1998 (i.e. group 1 contained 10\% of poviats with the lowest unemployment rates, while group 10 included the opposite $10 \%$ of poviats with highest initial unemployment rates). Since some of the municipal poviats did not exist in December 1998 - they were established as of January 2002 - this analysis was performed for 373 local labour markets. As earlier, Table 2 shows the summary of convergence in the upper panel and of catching up in the lower one. Numbers presented in columns reflect the structure of pairs in cointegrating or

${ }^{6}$ It has to be emphasised, that the evidence is of rather qualitative nature and this contention has not been tested quantitatively, to the best of our knowledge 
TYROWICZ, WÓJCIK Nonlinear Stochastic Convergence of Unemployment

Table 1: Relationships with Respect to Voivodship of Origin

\begin{tabular}{|c|c|c|c|c|c|c|c|c|c|c|c|c|c|c|c|c|}
\hline Voivodship & $\bar{~} 1$ & 2 & 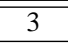 & 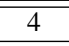 & $\overline{5}$ & $\overline{6} 6$ & $\overline{7}$ & 8 & 9 & 10 & 111 & 12 & 13 & 14 & 15 & 16 \\
\hline & \multicolumn{16}{|c|}{ Convergence } \\
\hline 1 & 8 & 5 & 5 & 8 & 7 & 11 & 6 & 8 & 5 & 6 & 7 & 5 & 1 & 4 & 6 & 6 \\
\hline 2 & 6 & 8 & 9 & 6 & 5 & 9 & 7 & 10 & 7 & 7 & 5 & 7 & 8 & 8 & 4 & 9 \\
\hline 3 & 6 & 9 & 7 & 3 & 10 & 5 & 10 & 4 & 10 & 8 & 10 & 5 & 9 & 11 & 6 & 6 \\
\hline 4 & 3 & 2 & 1 & 4 & 2 & 4 & 1 & 4 & 3 & 2 & 2 & 3 & 1 & 1 & 4 & 3 \\
\hline 5 & 7 & 4 & 8 & 5 & 7 & 6 & 5 & 6 & 6 & 6 & 8 & 4 & 7 & 4 & 7 & 9 \\
\hline 6 & 8 & 5 & 3 & 8 & 4 & 2 & 4 & 4 & 5 & 2 & 3 & 7 & 2 & 4 & 6 & 4 \\
\hline 7 & 13 & 13 & 17 & 8 & 10 & 11 & 12 & 9 & 15 & 18 & 9 & 9 & 19 & 12 & 11 & 13 \\
\hline 8 & 4 & 4 & 1 & 5 & 3 & 2 & 2 & 5 & 2 & 1 & 4 & 2 & 1 & 6 & 3 & 5 \\
\hline 9 & 4 & 5 & 7 & 6 & 5 & 6 & 6 & 3 & 4 & 6 & 5 & 5 & 7 & 8 & 4 & 3 \\
\hline 10 & 7 & 7 & 7 & 5 & 7 & 3 & 10 & 2 & 7 & 7 & 8 & 5 & 11 & 9 & 5 & 4 \\
\hline 11 & 6 & 4 & 6 & 3 & 6 & 4 & 4 & 7 & 5 & 6 & 3 & 5 & 3 & 4 & 7 & 5 \\
\hline 12 & 5 & 6 & 4 & 7 & 4 & 10 & 4 & 5 & 6 & 4 & 6 & 11 & 4 & 5 & 10 & 9 \\
\hline 13 & 1 & 4 & 4 & 1 & 4 & 1 & 5 & 2 & 4 & 6 & 2 & 2 & 9 & 3 & 2 & 3 \\
\hline 14 & 4 & 7 & 8 & 2 & 4 & 5 & 6 & 11 & 9 & 8 & 5 & 4 & 5 & 6 & 2 & 6 \\
\hline 15 & 7 & 4 & 6 & 12 & 8 & 11 & 7 & 7 & 6 & 5 & 11 & 12 & 5 & 3 & 12 & 6 \\
\hline 16 & 10 & 14 & 8 & 15 & 15 & 11 & 11 & 17 & 7 & 7 & 10 & 15 & 8 & 11 & 9 & 8 \\
\hline Total & 390 & 476 & 502 & 149 & 394 & 284 & 814 & 198 & 336 & 433 & 317 & 406 & 226 & 367 & 472 & 690 \\
\hline \multirow[t]{3}{*}{ Per 1 poviat } & 13.4 & 20.7 & 20.9 & 10.6 & 16.4 & 12.9 & 19.4 & 18.0 & 13.4 & 25.5 & 15.9 & 11.3 & 16.1 & 17.5 & 14.3 & 32.9 \\
\hline & \multicolumn{16}{|c|}{ Average on the diagonal: 7.1} \\
\hline & \multicolumn{16}{|c|}{ Catching-up } \\
\hline 1 & 7 & 6 & 2 & 12 & 12 & 8 & 4 & 16 & 4 & 5 & 5 & 15 & 3 & 8 & 14 & 6 \\
\hline 2 & 5 & 3 & 7 & 0 & 9 & 9 & 5 & 0 & 6 & 11 & 5 & 8 & 0 & 4 & 1 & 6 \\
\hline 3 & 1 & 4 & 4 & 0 & 3 & 1 & 8 & 0 & 2 & 6 & 5 & 1 & 8 & 2 & 0 & 4 \\
\hline 4 & 6 & 0 & 0 & 0 & 3 & 8 & 2 & 0 & 2 & 2 & 5 & 7 & 0 & 0 & 4 & 4 \\
\hline 5 & 10 & 10 & 7 & 6 & 4 & 8 & 8 & 16 & 7 & 5 & 6 & 3 & 3 & 6 & 4 & 6 \\
\hline 6 & 6 & 10 & 2 & 14 & 8 & 11 & 5 & 12 & 8 & 6 & 3 & 1 & 14 & 5 & 5 & 6 \\
\hline 7 & 4 & 6 & 17 & 4 & 9 & 5 & 8 & 0 & 7 & 15 & 5 & 3 & 22 & 4 & 7 & 6 \\
\hline 8 & 4 & 0 & 0 & 0 & 4 & 3 & 0 & 0 & 3 & 2 & 2 & 0 & 0 & 2 & 1 & 2 \\
\hline 9 & 4 & 8 & 4 & 4 & 8 & 9 & 7 & 12 & 0 & 14 & 7 & 5 & 11 & 2 & 4 & 10 \\
\hline 10 & 3 & 9 & 9 & 2 & 3 & 4 & 10 & 4 & 9 & 6 & 4 & 1 & 5 & 2 & 0 & 3 \\
\hline 11 & 7 & 10 & 15 & 16 & 10 & 4 & 7 & 12 & 11 & 9 & 11 & 10 & 11 & 10 & 19 & 9 \\
\hline 12 & 15 & 10 & 2 & 14 & 3 & 1 & 3 & 0 & 5 & 2 & 8 & 2 & 5 & 18 & 11 & 9 \\
\hline 13 & 1 & 0 & 7 & 0 & 1 & 5 & 8 & 0 & 4 & 3 & 3 & 2 & 5 & 0 & 1 & 2 \\
\hline 14 & 6 & 5 & 4 & 0 & 6 & 5 & 4 & 8 & 2 & 3 & 6 & 16 & 0 & 6 & 8 & 9 \\
\hline 15 & 9 & 1 & 0 & 6 & 3 & 4 & 5 & 4 & 3 & 0 & 10 & 8 & 3 & 6 & 8 & 3 \\
\hline 16 & 13 & 18 & 20 & 20 & 14 & 15 & 14 & 16 & 24 & 12 & 15 & 19 & 11 & 23 & 11 & 15 \\
\hline Total & 109 & 79 & 46 & 49 & 93 & 93 & 98 & 25 & 95 & 65 & 146 & 105 & 37 & 93 & 73 & 234 \\
\hline \multirow[t]{2}{*}{ Per 1 poviat } & 3.8 & 3.4 & 1.9 & 3.5 & 3.9 & 4.2 & 2.3 & 2.3 & 3.8 & 3.8 & 7.3 & 2.9 & 2.6 & 4.4 & 2.2 & 11.1 \\
\hline & \multicolumn{16}{|c|}{ Average on the diagonal: 5.6} \\
\hline
\end{tabular}

catching-up relation within each of the decile groups.

It is interesting to observe that except for the middle groups (5th and 6 th deciles) - convergence occurs most frequently towards poviats with relatively higher unemployment rates (8th 
Review of Economic Analysis 3 (2010) 59-79

Table 2: Structure of Relationships with Respect to the Initial Level of Unemployment (decimal group)

\begin{tabular}{|c|c|c|c|c|c|c|c|c|c|c|}
\hline Decimal groups & 1 & 2 & 3 & 4 & 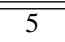 & $\overline{6}$ & 7 & 8 & 9 & 10 \\
\hline & \multicolumn{10}{|c|}{ Convergence } \\
\hline Decimal group 1 & 14 & 12 & 5 & 5 & 3 & 4 & 4 & 4 & 4 & 3 \\
\hline Decimal group 2 & 13 & 12 & 7 & 7 & 5 & 3 & 4 & 5 & 2 & 2 \\
\hline Decimal group 3 & 10 & 15 & 12 & 12 & 12 & 8 & 8 & 11 & 10 & 8 \\
\hline Decimal group 4 & 11 & 14 & 12 & 12 & 9 & 9 & 9 & 10 & 9 & 8 \\
\hline Decimal group 5 & 7 & 11 & 14 & 10 & 8 & 12 & 12 & 11 & 13 & 14 \\
\hline Decimal group 6 & 12 & 10 & 11 & 13 & 15 & 15 & 19 & 16 & 18 & 17 \\
\hline Decimal group 7 & 8 & 7 & 8 & 9 & 10 & 12 & 10 & 9 & 9 & 11 \\
\hline Decimal group 8 & 10 & 12 & 13 & 12 & 12 & 13 & 11 & 11 & 14 & 12 \\
\hline Decimal group 9 & 8 & 3 & 9 & 8 & 10 & 11 & 9 & 10 & 7 & 10 \\
\hline Decimal group 10 & 8 & 6 & 10 & 10 & 15 & 14 & 14 & 13 & 14 & 15 \\
\hline Total & 305 & 323 & 642 & 621 & 732 & 944 & 616 & 762 & 571 & 796 \\
\hline \multirow[t]{3}{*}{ Per 1 poviat } & 8.2 & 8.7 & 16.9 & 16.8 & 19.8 & 24.8 & 16.6 & 20.1 & 15.4 & 21.5 \\
\hline & \multicolumn{10}{|c|}{ Average on the diagonal: 11.6} \\
\hline & \multicolumn{10}{|c|}{ Catching up } \\
\hline Decimal group 1 & 13 & 5 & 5 & 7 & 12 & 9 & 10 & 11 & 11 & 6 \\
\hline Decimal group 2 & 8 & 4 & 12 & 14 & 10 & 13 & 21 & 18 & 32 & 24 \\
\hline Decimal group 3 & 5 & 6 & 5 & 4 & 9 & 6 & 19 & 8 & 12 & 12 \\
\hline Decimal group 4 & 6 & 6 & 3 & 8 & 3 & 8 & 8 & 10 & 9 & 8 \\
\hline Decimal group 5 & 15 & 7 & 11 & 5 & 4 & 9 & 14 & 15 & 14 & 14 \\
\hline Decimal group 6 & 12 & 9 & 8 & 12 & 9 & 5 & 11 & 11 & 13 & 18 \\
\hline Decimal group 7 & 7 & 8 & 13 & 6 & 7 & 6 & 3 & 4 & 2 & 2 \\
\hline Decimal group 8 & 13 & 12 & 9 & 14 & 14 & 10 & 6 & 4 & 3 & 10 \\
\hline Decimal group 9 & 12 & 19 & 13 & 11 & 12 & 11 & 3 & 3 & 0 & 3 \\
\hline Decimal group 10 & 10 & 24 & 21 & 18 & 20 & 24 & 6 & 16 & 5 & 3 \\
\hline Total & 121 & 216 & 120 & 99 & 151 & 158 & 80 & 140 & 129 & 214 \\
\hline \multirow[t]{2}{*}{ Per 1 poviat } & 3.3 & 5.8 & 3.2 & 2.7 & 4.1 & 4.2 & 2.2 & 3.7 & 3.5 & 5.8 \\
\hline & \multicolumn{10}{|c|}{ Average on the diagonal: 4.9} \\
\hline
\end{tabular}

and 10th deciles). Looking at the diagonal of the table one can observe relatively high percentage in extreme decimal groups, which suggests that to some extent convergence of clubs is observed. Convergence is ound relatively more often separately for poviats with highest and with lowest unemployment rates. Analysing the total number of converging relationships, more long-run convergence predictions are observed for poviats with higher unemployment rates and relatively few for first decimal group (poviats with lowest unemployment rates). Therefore not only spatial dimension, but also "initial" level of unemployment rate relates to the convergence pattern of unemployment in Poland.

The lower panel of Table 2 shows analogous summary of the initial unemployment level dimension for catching-up. Clearly, catching up is a much less frequent phenomenon. In fact, poviats with relatively low unemployment levels initially ( $2 n d$ decile) seem to catch-up with poviats from higher unemployment rates (7th-10th deciles) while the local labour markets with the highest unemployment rate catch up with the least troubled ones. This observation may be associated with the peculiar organisation of the municipal and rural local labour markets. 


\section{TYROWICZ, WÓJCIK Nonlinear Stochastic Convergence of Unemployment}

Namely, municipalities form separate units from the regions surrounding them in space. While these are the cities that provide most jobs and workers from the adjacent regions tend to commute to work (insufficient local labour demand).

The final analysis takes into account structural similarities between poviats and seeks for convergence or catching-up with respect to the cluster in which poviat is situated. Table 3 summarizes the results. It seems that this grouping of local labour markets provides most "predictive power". In fact, if we multiply the average diagonal with the length of the diagonal, we will obtain the values of 113, 116 and 123 for spatial, distributional and structural dimensions, respectively. Additionally, for the phenomenon of catching up, these values are 90, 49 and 106, respectively, which further corroborates the initial finding, that cluster analysis performs best.

Both convergence and catching up seem to occur between in roughly $20 \%$ of the cases from most clusters towards the 6 th segment, while strong convergence patterns emerge also for $1 \mathrm{st}$, 5 th and 8 th segment. Segment 1 is characterised by low inflow as well as outflows rates as well as relatively high shares of unemployed living in the rural areas. These labour markets are not only stagnant, but also - so to say - no longer characterised by high long-term unemployment rates or high share of delisted in outflows. This implies that in fact this segment covers labour markets where a large part of the labour force is already discouraged, i.e. does not actively seek employment, especially women. These last two characteristics are shared with segments 10 and 6 - they also have relatively lower female unemployment rates and low rates of delisted in outflows, but are not rural. The contrary example is provided by segment 5 , which has no dominat characteristics. While this is a relatively small cluster (only 31 local labour markets), as much as $20 \%$ of its local labour units demonstrate convergence with segment 6 - recognised earlier as characteristic.

Also catching up occurs most frequently with the poviats of segment 6 . While the diagonal values in the lower panel of Table 3 are fairly similar to the upper panel, average per poviat number of cointegrating relations is much lower. Thus, there seems to be considerably more catching up within than between the segments, relatively speaking. The within cluster catching-up process is again strongest in cluster 1 - i.e. among rural, distant labour markets with low dynamics. Also, cluster 6 - similarly stagnant but municipal - has over $20 \%$ of pairs demonstrating convergence.

Comparing the results for all dimensions analyzed, one can conclude that the structural similarity of poviats has highest influence both on convergence and catching-up process. Clustering allowed to identify groups of local labour markets - either very characteristic as segments 1, 6 or without a dominating pattern but with internally similar composition of unemployment, as segment 5 - which tend to experience pair wise convergence more frequently. Naturally, the finding that structurally similar units seem to demonstrate convergence is not a spectacular one. However, comparison of the three groupings - spatial, distributional and structural - revealed that in fact the internal labour market characteristics seem to coincide with the cointegration 
Review of Economic Analysis 3 (2010) 59-79

Table 3: Structure of Converging Relationships with Respect to the Segment of Origin

\begin{tabular}{|c|c|c|c|c|c|c|c|c|c|c|}
\hline Cluster & 1 & 2 & 3 & 4 & 5 & 6 & 7 & 8 & 9 & 10 \\
\hline & \multicolumn{10}{|c|}{ Convergence } \\
\hline Cluster 1 & 25 & 11 & 18 & 10 & 16 & 18 & 13 & 22 & 13 & 29 \\
\hline Cluster 2 & 5 & 11 & 11 & 8 & 7 & 8 & 16 & 8 & 6 & 13 \\
\hline Cluster 3 & 15 & 19 & 13 & 16 & 15 & 15 & 12 & 15 & 14 & 9 \\
\hline Cluster 4 & 4 & 7 & 7 & 16 & 6 & 8 & 12 & 4 & 12 & 4 \\
\hline Cluster 5 & 9 & 9 & 10 & 9 & 14 & 10 & 11 & 10 & 12 & 7 \\
\hline Cluster 6 & 21 & 21 & 22 & 24 & 20 & 22 & 19 & 20 & 18 & 25 \\
\hline Cluster 7 & 1 & 3 & 1 & 3 & 2 & 1 & 2 & 1 & 4 & 2 \\
\hline Cluster 8 & 18 & 16 & 15 & 9 & 16 & 15 & 10 & 17 & 17 & 13 \\
\hline Cluster 9 & 1 & 1 & 2 & 3 & 2 & 2 & 5 & 2 & 3 & 0 \\
\hline Cluster 10 & 1 & 1 & 1 & 0 & 1 & 1 & 1 & 1 & 0 & 0 \\
\hline Total & 1184 & 527 & 969 & 444 & 654 & 1373 & 108 & 1013 & 126 & 56 \\
\hline \multirow[t]{3}{*}{ Per 1 poviat } & 20.1 & 13.5 & 17.6 & 8.7 & 21.1 & 23.3 & 9.8 & 17.5 & 12.6 & 9.3 \\
\hline & \multicolumn{10}{|c|}{ Average on the diagonal: 12.3} \\
\hline & \multicolumn{10}{|c|}{ Catching up } \\
\hline Cluster 1 & 28 & 10 & 13 & 4 & 8 & 12 & 0 & 18 & 0 & 0 \\
\hline Cluster 2 & 10 & 9 & 18 & 13 & 16 & 12 & 5 & 17 & 9 & 33 \\
\hline Cluster 3 & 11 & 15 & 5 & 10 & 12 & 11 & 24 & 7 & 21 & 17 \\
\hline Cluster 4 & 4 & 14 & 14 & 18 & 16 & 16 & 10 & 16 & 6 & 0 \\
\hline Cluster 5 & 6 & 13 & 11 & 12 & 14 & 8 & 19 & 9 & 15 & 0 \\
\hline Cluster 6 & 19 & 18 & 20 & 24 & 15 & 23 & 29 & 18 & 27 & 17 \\
\hline Cluster 7 & 0 & 1 & 3 & 1 & 3 & 2 & 0 & 1 & 0 & 0 \\
\hline Cluster 8 & 21 & 19 & 10 & 17 & 13 & 13 & 14 & 9 & 21 & 33 \\
\hline Cluster 9 & 0 & 2 & 5 & 1 & 3 & 3 & 0 & 3 & 0 & 0 \\
\hline Cluster 10 & 0 & 1 & 1 & 0 & 0 & 0 & 0 & 1 & 0 & 0 \\
\hline Total & 183 & 191 & 154 & 201 & 146 & 291 & 21 & 214 & 33 & 6 \\
\hline \multirow[t]{2}{*}{ Per 1 poviat } & 3.1 & 4.9 & 2.8 & 3.9 & 4.7 & 4.9 & 1.9 & 3.7 & 3.3 & 1.0 \\
\hline & \multicolumn{10}{|c|}{ Average on the diagonal: 10,6} \\
\hline
\end{tabular}

of unemployment rates more frequently than regional coordination or similar initial unemployment rate levels.

\section{Conclusions}

Social cohesion necessitates not only lowering the unemployment rates, but also convergence among regions. While lack of the latter implies that the national average is uninformative, it also suggests that either the response to both positive and adverse labour demand shocks is different across regions or that these responses leave a lasting - non transitory - effect. While there is no single econometric tool that allows to verify the status quo, this analysis contributes to further understanding of the dynamics of regional unemployment rates in Poland - a country with traditionally highest unemployment rates in the EU.

Convergence of unemployment rates was tested for pairs consisting of 379 poviats. Longrun relationships with the national average were found for only few poviats. Testing of the convergence between all possible pairs of poviats suggested that roughly 5.5 per cent of pairs seem to demonstrate convergence or catching-up. We analyzed spatial, structural and distribu- 


\section{TYROWICZ, WÓJCIK Nonlinear Stochastic Convergence of Unemployment}

tional correlates of convergence occurrence, checking if pairs of poviats that seem to be tied by a long-run relationship (i) are close to each other in space (in the same region - voivodship); (ii) were initially characterised by similar unemployment levels; or (iii) seem to be structurally similar.

We conclude that convergence pattern of regional unemployment rates has to some extent spatial dimension - poviats from the East and separately from North and North-West seem to have relatively higher degree of convergence. Therefore, some convergence of clubs can be confirmed. However, regional coordination of the labour market policies does not seem to foster intra-regional covergence. In fact, initial unemployment rate level especially for the middle and top deciles seems to tell much more about the likelihood of convergence. It is also observed that convergence and catching-up appears more often within some poviats clusters, namely, stagnant local labour markets - be it rural or municipal. These findings combined seem to suggest that while convergence of clubs seems to occur in some regions of Poland, it may actually be associated with relative deterioration of the labour market outlooks.

In addition, more long-run convergence predictions are observed for poviats with higher unemployment rates and relatively few for poviats with lowest unemployment rates. This suggests that units experiencing local labour markets hardships are probably reaching their limits in terms of the possible unemployment magnitudes and this naturally imposed ceiling necessitates stochastic convergence. On the other hand, neither middle-range nor lower level poviats seem to exhibit convergence with other regions, which suggests the cohesion policies have had limited effect for the time being.

Naturally, those pairs of the local labour markets that demonstrate "convergence", might in fact converge to levels permanently different between the groups of pairs. Thus, this study does not provide a complete answer to the question about trends in social cohesion in Poland. We have applied a non-linear version of the stochastic convergence in order to control for the diverging convergence rates. We have applied this instrument to all possible pairs of poviats to verify how frequently this phenomenon occurs and whether some regions of Poland, structural clusters or units with similar unemployment rate experience it more frequently. The findings undermine the effectiveness of regional coordination and suggest that the initially high unemployment rates did not necessarily imply divergence. In fact, the convergence we found seems to be associated with stagnant labour markets, where due to the large number of discouraged workers, unemployment rate is no longer the key indicator of the labour market situation.

\section{References}

Armstrong, H. and Taylor, J. (2000), Regional Economics and Policy, 3rd edn, Blackwell.

Bayer, C. and Juessen, F. (2006), Convergence in West German Regional Unemployment Rates, University of Dortmund, mimeo. 
Bernard, A. B. and Durlauf, S. N. (1995), Convergence in International Output, Journal of Applied Econometrics 10(2), 97-108.

Bernard, A. B. and Durlauf, S. N. (1996), Interpreting Tests of the Convergence Hypothesis, Journal of Econometrics 71(1), 161-173.

Bräuninger, M. and Niebuhr, A. (2005), Convergence, Spatial Interaction and Agglomeration Effects in the EU, ERSA conference papers ERSA 05/528, European Regional Science Association.

Buettner, T. (1999), The Effect of Unemployment, Aggregate Wages and Spatial Contiguity on Local Wages: An Investigation with German Distric Level Data, Papers in Regional Science $78,47-67$.

Campbell, J. and Mankiw, N. (1989), International evidence on the persistence of economic fluctuations, Journal of Monetary Economics 23, 319-333.

Carlino, G. and Mills, L. (1993), Are U.S. regional incomes converging? A time series analysis, Journal of Monetary Economics 32, 335-346.

Cellini, R. and Scorcu, A. (2000), Segmented stochastic convergence across the G-7 countries, Empirical Economics 25, 463-474.

Chong, T. T. L., Hinich, M. J., Liew, K. S. and Lim, K. P. (2008), Time Series Test of Nonlinear Convergence and Transitional Dynamics, Economic Letters 100, 337-339.

Cogley, T. (1990), International evidence on the size of the random walk in output, Journal of Political Economy 91, 501-518.

Elliott, G., Rothenberg, T. J. and Stock, J. H. (1996), Efficient Tests for an Autoregressive Unit Root, Econometrica (64), 813-836.

Ferragina, A. M. and Pastore, F. (2008), Mind the Gap: Unemployment in the New EU Regions, Journal of Economic Surveys 22(1), 73-113.

Gomes, F. A. R. and da Silva, C. G. (2006), Hysteresis vs. Nairu and Convergence vs. Divergence: The Behavior Of Regional Unemployment Rates In Brazil, Anais do XXXIV Encontro Nacional de Economia [Proceedings of the 34th Brazilian Economics Meeting] 161, ANPEC - Associaçao Nacional dos Centros de Pósgraduaçao em Economia [Brazilian Association of Graduate Programs in Economics].

Greasley, D. and Oxley, L. (1997), Time-series based tests of the convergence hypothesis: Some positive results, Economics Letters 56(2), 143-147.

Góra, M. and Lehman, H. (1995), How Divergent is Regional Labour Market Adjustment in Poland?, in S. Scarpetta and A. Wörgötter (eds), The Regional Dimension of Unemployment in Transition Countries. A Challenge for Labour Market and Social Policies, OECD.

Kaczmarczyk, P. and Tyrowicz, J. (2008), Wspólczesne procesy migracyjne w Polsce “Contemporaneous Migration Processes from Poland", Fundacja Inicjatyw SpolecznoEkonomicznych, Warszawa. 
TYROWICZ, WÓJCIK Nonlinear Stochastic Convergence of Unemployment

Kapetanios, G., Shin, Y. and Snell, A. (2003), Testing for a unit root in the nonlinear STAR framework, Journal of Econometrics 112, 359-379.

Manning, N. (1994), Earnings, Unemployment and Contiguity: Evidence from British Counties 1976-1992, Scottish Journal of Political Economy 41, 43-68.

Martin, R. W. (2004), Can Black Workers Escape Spatial Mismatch? Employment Shifts, Population Shifts, and Black Unemployment in American Cities, Journal of Urban Economics 55(1), 179-194.

Meyer, B. D. and Sullivan, J. X. (2003), Measuring the Well-Being of the Poor Using Income and Consumption, NBER Working Papers 9760, National Bureau of Economic Research.

Molho, I. (1995), Spatial Autocorrelation In British Unemployment, Journal of Regional Science 35(4), 641-658.

Niebuhr, A. (2003), Spatial Interaction and Regional Unemployment in Europe, European Journal of Spatial Development 5, 1-26.

Niebuhr, A. and Stiller, S. (2004), Integration and Labour Markets in European Border Regions, ERSA conference papers ERSA 04/29, European Regional Science Association.

Overman, H. and Puga, D. (2002), Regional Unemployment Clusters, Economic Policy 17(34), 115-148.

Oxley, L. and Greasley, D. (1995), A time-series perspective on convergence: Australia, UK and USA since 1870, The Economic Record 214(71), 259-270.

Pesaran, H. M. (2009), A pair-wise approach to testing for output and growth convergence, Journal of Econometrics 1(138), 312-355.

Pesaran, H. M., Smith, R. P., Takashi, Y. and Hvozdyk, L. (2009), Pairwise tests of purchasing power parity, Econometric Reviews (28), 495-521.

Rogers, C. L. (1997), Job Search and Unemployment Duration: Implications for the Spatial Mismatch Hypothesis, Journal of Urban Economics 42(1), 109-132.

St. Aubyn, M. (1999), Convergence across industrialised countries (1890-1989): New results using time series methods, Empirical Economics 241, 23-44.

Südekum, J. (2003), Increasing Returns and Spatial Unemployment Disparities, Departmental Discussion Papers 117, University of Goettingen, Department of Economics.

Tyrowicz, J. and Wójcik, P. (2010a), Regional Dynamics of Unemployment in Poland - A Convergence Approach, in F. Caroleo and F. Pastore (eds), A New Regional Geography of Europe?, Physica/Verlag.

Tyrowicz, J. and Wójcik, P. (2010b), Unemployment Convergence in Transition, in E. Marelli and M. Signorelli (eds), Growth and Labour Market in Transition: A Comparative Perspective, Studies in Economic Transition, Palgrave-MacMillan.

Wasmer, E. and Zenou, Y. (2006), Equilibrium Search Unemployment with Explicit Spatial Frictions, Labour Economics 13(2), 143-165. 
Review of Economic Analysis 3 (2010) 59-79

\section{Appendix}

Synthetic Results of Convergence With the National Average

Table 4: Relationships With the Average Unemployment Rate

\begin{tabular}{|c|c|c|c|c|}
\hline Voivodship & Catching-up & Convergence & Divergence & Total \\
\hline & \multicolumn{4}{|c|}{ Number of poviats by voivodship of origin } \\
\hline dolnoslaskie & 0 & 2 & 27 & 29 \\
\hline kujawsko-pomorskie & 0 & 1 & 22 & 23 \\
\hline lubelskie & 0 & 1 & 23 & 24 \\
\hline lubuskie & 0 & 0 & 14 & 14 \\
\hline lodzkie & 0 & 2 & 22 & 24 \\
\hline malopolskie & 0 & 0 & 22 & 22 \\
\hline mazowieckie & 0 & 0 & 42 & 42 \\
\hline opolskie & 0 & 0 & 12 & 12 \\
\hline podkarpackie & 2 & 0 & 23 & 25 \\
\hline podlaskie & 0 & 0 & 17 & 17 \\
\hline pomorskie & 0 & 1 & 19 & 20 \\
\hline slaskie & 0 & 1 & 35 & 36 \\
\hline swietokrzyskie & 0 & 0 & 14 & 14 \\
\hline warminsko-mazurskie & 0 & 1 & 20 & 21 \\
\hline wielkopolskie & 0 & 2 & 33 & 35 \\
\hline zachodniopomorskie & 0 & 5 & 16 & 21 \\
\hline \multirow[t]{2}{*}{ Total } & 2 & 16 & 361 & 379 \\
\hline & \multicolumn{4}{|c|}{ Number of poviats by the initial decile } \\
\hline Decimal group 1 & 0 & 1 & 36 & 37 \\
\hline Decimal group 2 & 0 & 0 & 37 & 37 \\
\hline Decimal group 3 & 0 & 2 & 36 & 38 \\
\hline Decimal group 4 & 0 & 1 & 36 & 37 \\
\hline Decimal group 5 & 2 & 2 & 33 & 37 \\
\hline Decimal group 6 & 0 & 3 & 35 & 38 \\
\hline Decimal group 7 & 0 & 1 & 36 & 37 \\
\hline Decimal group 8 & 0 & 2 & 36 & 38 \\
\hline Decimal group 9 & 0 & 0 & 37 & 37 \\
\hline \multirow[t]{2}{*}{ Decimal group 10} & 0 & 4 & 33 & 37 \\
\hline & 0 & 0 & 6 & 6 \\
\hline \multirow[t]{2}{*}{ Total } & 2 & 16 & 361 & 379 \\
\hline & \multicolumn{4}{|c|}{ Number of poviats by cluster } \\
\hline Cluster 1 & 0 & 2 & 57 & 59 \\
\hline Cluster 2 & 0 & 2 & 37 & 39 \\
\hline Cluster 3 & 2 & 2 & 51 & 55 \\
\hline Cluster 4 & 0 & 1 & 50 & 51 \\
\hline Cluster 5 & 0 & 3 & 28 & 31 \\
\hline Cluster 6 & 0 & 3 & 56 & 59 \\
\hline Cluster 7 & 0 & 0 & 11 & 11 \\
\hline Cluster 8 & 0 & 2 & 56 & 58 \\
\hline Cluster 9 & 0 & 1 & 9 & 10 \\
\hline Cluster 10 & 0 & 0 & 6 & 6 \\
\hline Total & 2 & 16 & 361 & 379 \\
\hline
\end{tabular}

Note: Results for poviats exhibiting relationship to the national average unemployment rate. Some poviats did not exist in Dec 1998, therefore it was not possible to attribute initial decile group. 
TYROWICZ, WÓJCIK Nonlinear Stochastic Convergence of Unemployment

Table 5: Converging or Catching-up?

\begin{tabular}{c|c|c}
\hline \hline result & poviat & voivodship \\
\hline \hline convergence & lubinski & dolnoslaskie \\
convergence & milicki & dolnoslaskie \\
convergence & wabrzeski & kujawsko-pomorskie \\
convergence & pulawski & lubelskie \\
convergence & slupski & pomorskie \\
convergence & mragowski & warminsko-mazurskie \\
convergence & kaliski & wielkopolskie \\
convergence & ostrowski wielkopolski & wielkopolskie \\
convergence & goleniowski & zachodniopomorskie \\
convergence & kamieński & zachodniopomorskie \\
convergence & Koszalin city & zachodniopomorskie \\
convergence & kolobrzeski & zachodniopomorskie \\
convergence & slawienski & zachodniopomorskie \\
convergence & Dabrowa Gornicza city & slaskie \\
convergence & belchatowski & lodzkie \\
convergence & skierniewicki & lodzkie \\
\hline catching-up & mielecki & podkarpackie \\
catching-up & stalowowolski & podkarpackie \\
\hline \hline
\end{tabular}

Note: poviats exhibiting convergence or catching up with respect to dynamics of the national unemployment rate. 